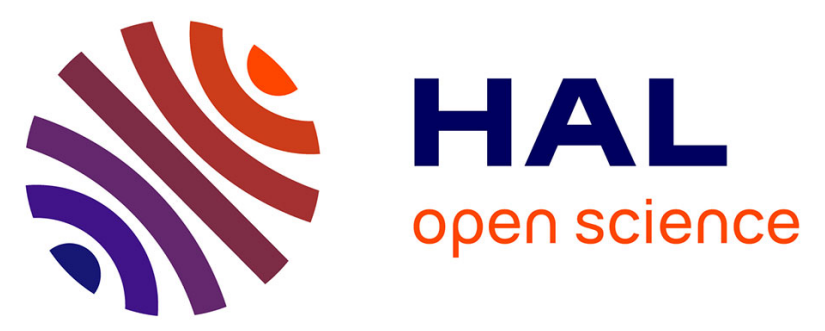

\title{
New isotopic constraints on age and magma genesis of an embryonic oceanic crust: The Chenaillet Ophiolite in the Western Alps
}

Xian-Hua Li, Michel Faure, Wei Lin, Gianreto Manatschal

\section{- To cite this version:}

Xian-Hua Li, Michel Faure, Wei Lin, Gianreto Manatschal. New isotopic constraints on age and magma genesis of an embryonic oceanic crust: The Chenaillet Ophiolite in the Western Alps. Lithos, 2013, 160-161, pp.283-291. 10.1016/j.lithos.2012.12.016 . insu-00859595

\section{HAL Id: insu-00859595}

https://hal-insu.archives-ouvertes.fr/insu-00859595

Submitted on 13 Dec 2013

HAL is a multi-disciplinary open access archive for the deposit and dissemination of scientific research documents, whether they are published or not. The documents may come from teaching and research institutions in France or abroad, or from public or private research centers.
L'archive ouverte pluridisciplinaire HAL, est destinée au dépôt et à la diffusion de documents scientifiques de niveau recherche, publiés ou non, émanant des établissements d'enseignement et de recherche français ou étrangers, des laboratoires publics ou privés. 


\section{New isotopic constraints on age and magma genesis of an embryonic oceanic crust: The Chenaillet Ophiolite in the Western Alps}

- Xian-Hua Li ${ }^{\mathrm{a}}$,

- Michel Faure $^{\mathrm{b}}$

- Wei Lin $^{\mathrm{a}}$

- Gianreto Manatschal $^{\mathrm{c}}$

- ${ }^{\text {a }}$ State Key Laboratory of Lithospheric Evolution, Institute of Geology and Geophysics, Chinese Academy of Sciences, Beijing 100029, China

- $\quad{ }^{\mathrm{b}}$ Institut des Sciences de la Terre d'Orléans, CNRS-Université d'Orléans, 45067 Orléans Cedex 2, France

- $\quad{ }^{\mathrm{c}}$ Institut de Physique du Globe de Strasbourg, CNRS UMR7516, Université de Strasbourg, 1 rue Blessig, 67084 Strasbourg, France

\section{Abstract}

The Chenaillet Ophiolite is one of the best-preserved remnants of the Piemont-Liguria oceanic basin, a branch of the Central Atlantic that opened during the separation of Adria/Africa from Europe. Despite numerous studies of structure, petrology, geochemistry and isotope geochronology, the timing and genesis of various magmatic rocks within the Chenaillet Ophiolite are still controversial. We provide in this study integrated in situ analyses of zircon $\mathrm{U}-\mathrm{Pb}$ age and $\mathrm{O}-\mathrm{Hf}$ isotopes for the troctolite and albitite within the Chenaillet Ophiolite. Our new results indicate that the troctolite and albitite crystallized synchronously at $\sim 165 \mathrm{Ma}$. Zircons from the troctolite have homogeneous $\mathrm{Hf}$ and $\mathrm{O}$ isotopic compositions, with $\varepsilon \mathrm{Hf}(\mathrm{T})=+13.5 \pm 1.0(2 \mathrm{SD})$ and $\delta^{18} \mathrm{O}=5.4 \pm 0.4 \%$ (2SD), indicating crystallization from magmas that were derived from a depleted, MORB-like mantle. The albitite zircons give consistent $\varepsilon H f(T)$ values $(+13.0$ to +13.5$)$ within errors with those of troctolite zircons, but variable $\delta^{18} \mathrm{O}$ values. The altered zircon domains have relatively low $\delta^{18} \mathrm{O}$ values of $4.7 \pm 0.6 \%$ (2SD) due to subsolidus hydrothermal alteration, whilst the least-altered zircon domains give $\delta^{18} \mathrm{O}_{\text {zir }}$ values of $5.1 \pm 0.4 \%$ (2SD), indistinguishable within errors with the troctolite zircons and the igneous zircons from the Mid-Atlantic and Southwest Indian Ridges gabbros, norites, and plagiogranites of modern oceanic crust. In situ zircon O-Hf isotopic data suggest that the troctolites and albitites are most likely cogenetic, with the albitites being formed by extreme fractional crystallization from the basaltic magma.

Based on our new age results and compilation of the reliable literature $\mathrm{U}-\mathrm{Pb}$ age data, the ophiolitic gabbros from Eastern, Central and, Western Alps, Liguria and Corsica crystallized nearly synchronously at 158-166 Ma, suggesting a short life span of $<11 \mathrm{~m}$.y. for the formation of the Piemont-Liguria oceanic domain, rather than a 30 m.y. life span as previously thought. The Chenaillet ophiolite is likely a remnant of embryonic oceanic crust, rather than a piece of "mature" oceanic crust. Provided the spreading velocities of $<3 \mathrm{~cm} / \mathrm{yr}$ full rate for magma-poor MOR sequences, the maximum width to the Piemont-Liguria oceanic floor would have been in the order of $300 \mathrm{~km}$. 
Keywords : Zircon U-Pb age; Zircon O-Hf isotopes; Plagiogranites; Chenaillet ophiolite; Alpine Tethys; Piemont-Liguria oceanic basin

\section{Introduction}

The ophiolites exposed in the Western Alps, the Ligurides, the Northern Apennines and Corsica (Fig. 1A) represent remnants of the Piemont-Liguria basin that opened as a branch of the Central Atlantic during the separation of Adria/Africa from Europe (Lemoine et al., 1987). The timing of the opening, nature of the crust and development and life-span of this embryonic oceanic domain are crucial to the understanding of the Mesozoic evolution of the Alpine Tethyan realms and, in a more general way, to the understanding of how continents break apart and new oceans form.
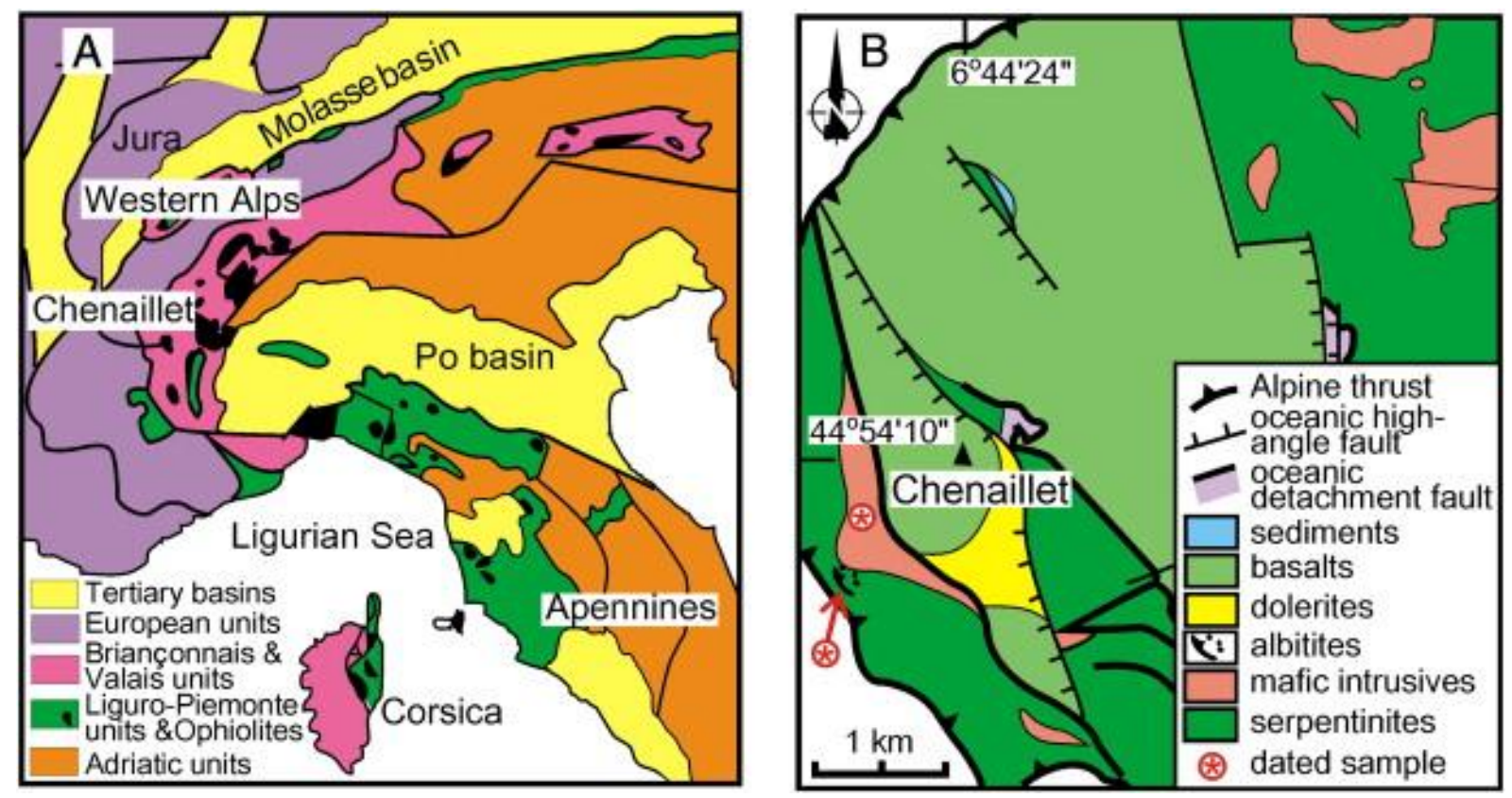

Fig. 1. : (A) Distribution of Ophiolite massifs in the Tertiary orogens from the Western Alps, the Ligurides, the Northern Apennines, and Corsica; (B) simplified geological map of the Chenaillet Ophiolite. Figures are modified after Manatschal and Müntener (2009) and Manatschal et al. (2011).

One of the best-preserved ophiolites in the Western Alps is the Chenaillet Ophiolite exposed along the French-Italian border south of Montgenèvre (Fig. 1B). The fact that this ophiolite escaped high-pressure metamorphism made it a preferred target to study the structure, petrology, geochemistry and isotope geochronology of a piece of ancient Jurassic oceanic crust (Bertrand et al., 1987, Caby, 1995 and Costa and Caby, 2001; Chalot-Prat et al., 2003; Chalot-Prat, 2005, Lewis and Snewing, 1980, Manatschal and Müntener, 2009, Manatschal et al., 2011 and Mével et al., 1978). In particular the present isotopic age data for the Chenaillet Ophiolite that cover a time span of 30-50 m.y., which is by far the largest among the dated Jurassic ophiolites in the Western Alps, casting some problems for the interpretation of this ophiolite as part of a normal spreading oceanic crust. In order to test the validity of these data, 
we carried out integrated in situ analyses of zircon $\mathrm{U}-\mathrm{Pb}$ age and $\mathrm{O}-\mathrm{Hf}$ isotopes for the troctolite and albitite from the Chenaillet Ophiolite. The aim of the study was to (1) provide robust age constraints on the timing of the opening of the oceanic domain preserved at the Chenaillet; (2) investigate the genetic relationships between the mafic and felsic magmatic rocks within the Chenaillet Ophiolite using integrated in situ zircon O-Hf isotopes. Our work indicates that the troctolites and albitites within the Chenaillet Ophiolite were not only contemporaneous, as they both crystallized at $\sim 165 \mathrm{Ma}$, but also cogenetic. These new isotopic data have significant implications for the timing of formation and the magmatic evolution of the Piemont-Liguria ocean basin.

\section{Geological background}

The Chenaillet Ophiolite exposed south of Montgenèvre along the Franco-Italian border represents a klippe emplaced over the strongly deformed blueschist facies bearing ReplatteLago Nero unit. The Chenaillet Ophiolite preserves primary oceanic contacts between serpentinized mantle and mafic intrusive rocks, sediments and MOR basalts (MORB) exposed over an area of about $25 \mathrm{~km}^{2}$ (Fig. 1B). In contrast to most ophiolites from the Western Alps that experienced a high-pressure/low-temperature metamorphism and polyphase tectonic overprint during their emplacement within the Alpine nappe stack, the Chenaillet Ophiolite never exceed prehnite-pumpellyite facies and the Alpine tectonic overprint is minor (Manatschal et al., 2011, and references therein). Major lithologies forming the Chenaillet Ophiolite comprise, from bottom to top, serpentinized mantle rocks, intrusive mafic and minor felsic rocks, volcanic sequences and sediments. The mantle rocks consist of strongly serpentinized lherzolites and harzburgites, as well as minor pyroxenites, dunites and wehrlites (Bertrand et al., 1987).

Intrusive mafic rocks consist of troctolites, gabbros, diorites and dolerites. A thin sequence of layered troctolites and olivine-bearing gabbros occur within highly serpentinized mantle rocks, forming discrete bodies of less than $1 \mathrm{~km}$ in diameter and showing evidence of synmagmatic deformation (Mével et al., 1978). The troctolites comprise plagioclase and olivine with minor clinopyroxene, whilst the gabbros consist of plagioclase and clinopyroxene, with minor olivine and opaque minerals. Costa and Caby (2001) interpreted the gabbros as remnants of an oceanic lower crust preserving a paleo-Moho with the mantle rocks. More recently, Manatschal et al. (2011) demonstrated that the mafic rocks form discrete bodies ( $<1 \mathrm{~km}$ in diameter) intrusive into serpentinized mantle. In contrast to the work of ChalotPrat (2005), we are not able to demonstrate that the gabbors are sill-like intrusions. They seem more to correspond to small magmatic bodies like those described from other ophiolites in the Alps (e.g.Desmurs et al., 2002). Dioritic rocks occur as veins, dykes with either diffuse or sharp boundaries with the gabbros (Costa and Caby, 2001 and Manatschal et al., 2011). Rock-forming minerals of the diorites include plagioclase, clinopyroxene and pargasitic amphibole. Dolerites and basaltic dykes outcrop within the sheared gabbros, particularly in the vicinity of high-angle faults, throughout the Chenaillet Ophiolite (Manatschal et al., 2011).

Albitites form dykes and sills that were emplaced within the serpentinized peridotites and the gabbros (Caby, 1995 and Chalot-Prat, 2005), and possibly within the pillow basalts as well (e.g. description of Chapelle, 1990). Albitites are the only felsic intrusive rocks identified within the Chenaillet Ophiolite. They are fine-grained, consisting predominantly of albite $(\geq 90 \%)$, magmatic amphibole pseudomorphosed into tremolite-actinolite, and accessory minerals such as allanite, apatite and zircon (Costa and Caby, 2001). 
A volcanic sequence overlies the mantle and intrusive mafic rocks, and locally also sediments (Manatschal et al., 2011). In contrast to Chalot-Prat (2005), we interpret the volcanic sequence that is locally up to $400 \mathrm{~m}$ thick to be formed by several magmatic events. This sequence consists of lava flows, pillow basalts, pillow breccias and hyaloclastites affinitive geochemically to the MORB (Bertrand et al., 1987 and Chalot-Prat, 2005). Sediments occur either between exhumed serpentinized mantle and intrusive mafic rocks and the volcanic sequence, or within the volcanic sequence (Manatschal et al., 2011).

A troctolite sample ALP3-6.3 (44 $\left.53^{\prime} 47^{\prime \prime} \mathrm{N}, 06^{\circ} 44^{\prime} 10^{\prime \prime} \mathrm{E}\right)$ and an albitite sample ALP3-6.1 $\left(44^{\circ} 53^{\prime} 40^{\prime \prime} \mathrm{N}, 06^{\circ} 43^{\prime} 53^{\prime \prime} \mathrm{E}\right)$ were collected from the southwestern Chenaillet Ophiolite complex (Fig. 1B) for in situ zircon U-Pb age and O-Hf isotope study.

\section{Analytical methods}

\subsection{Zircon $\mathrm{U}-\mathrm{Pb}$ dating}

Zircon concentrates were separated from a ca. $5-\mathrm{kg}$ of troctolite and a ca. 2-kg of albitite using standard density and magnetic separation techniques. Zircon grains, together with standard zircons TEMORA 2, 91500, Penglai and an in-house standard zircon Qinghu, were mounted in an epoxy mount that was then ground and polished to section the crystals in half for analysis. Zircons were documented with transmitted and reflected light photomicrographs as well as cathodoluminescence (CL) images to reveal their internal structures, and the mount was vacuum-coated with high-purity gold prior to SIMS analyses.

Measurements of $\mathrm{U}$, Th and $\mathrm{Pb}$ isotopes were conducted using a Cameca IMS $1280 \mathrm{SIMS}$ at the Institute of Geology and Geophysics, Chinese Academy of Sciences in Beijing. Analytical procedures are similar to those reported by $\mathrm{Li}$ et al. (2009). The primary $\mathrm{O}_{2}^{-}$ion beam spot is about $20 \times 30 \mu \mathrm{m}$ in size. Positive secondary ions were extracted with a $10 \mathrm{kV}$ potential. In the secondary ion beam optics, a $60 \mathrm{eV}$ energy window was used, together with a mass resolution of ca. 5400 (at 10\% peak height), to separate $\mathrm{Pb}^{+}$peaks from isobaric interferences. A single electron multiplier was used in ion-counting mode to measure secondary ion beam intensities by peak jumping mode. Analyses of the standard zircon TEMORA 2 were interspersed with unknown grains. Each measurement consists of 7 cycles. $\mathrm{Pb} / \mathrm{U}$ calibration was performed relative to zircon standard TEMORA $2\left({ }^{206} \mathrm{~Pb} /{ }^{238} \mathrm{U}\right.$ age $=417 \mathrm{Ma}$, Black et al., 2004); U and Th concentrations were calibrated against zircon standard 91500 ( $\mathrm{Th}=29 \mathrm{ppm}$, and $U=81 \mathrm{ppm}$, Wiedenbeck et al., 1995). Measured compositions were corrected for common $\mathrm{Pb}$ using non-radiogenic ${ }^{204} \mathrm{~Pb}$, and an average of crustal composition (Stacey and Kramers, 1975) is used for the common $\mathrm{Pb}$. Data reduction was carried out using the Isoplot/Ex v. 2.49 program (Ludwig, 2001). In order to monitor the external uncertainties of SIMS U-Pb zircon measurements, an in-house standard zircon Qinghu was alternately analysed as an unknown together with other unknowns. Twenty measurements on Qinghu zircon (Appendix Table 1) yield a Concordia age of $160 \pm 1 \mathrm{Ma}$ (2SE, MSWD of concordance $=0.92$ ), which is in good agreement within errors with the recommended $\mathrm{U}-\mathrm{Pb}$ age of $159.5 \pm 0.2 \mathrm{Ma}$ (Li et al., 2009). Zircon $\mathrm{U}-\mathrm{Pb}$ age data are presented in Appendix Table 1.

\subsection{Zircon oxygen isotopes}

Zircon oxygen isotopes were measured using the same Cameca IMS 1280 SIMS, with analytical procedures similar to those reported by Li et al. (2010a). Oxygen isotopic analyses 
were obtained on the same spots of zircon grains that were previously analyzed for $\mathrm{U}-\mathrm{Pb}$ age determinations. After $\mathrm{U}-\mathrm{Pb}$ dating, the sample mount was re-ground and re-polished to ensure that any oxygen implanted in the zircon surface from the $\mathrm{O}_{2}^{-}$beam used for $\mathrm{U}-\mathrm{Pb}$ determination was removed. The $\mathrm{Cs}^{+}$primary ion beam was accelerated at $10 \mathrm{kV}$, with an intensity of $\sim 2.5 \mathrm{nA}$ corresponding to a beam size of $\sim 10 \mu \mathrm{m}$ in diameter. The normal incidence electron flood gun was used to compensate for sample charging. Negative secondary ions were extracted with a $-10 \mathrm{kV}$ potential. Oxygen isotopes were measured in multi-collection mode using two off-axis Faraday cups. The mass resolution used to measure oxygen isotopes was ca. 2500 (at $10 \%$ peak height). Measured ${ }^{18} \mathrm{O} /{ }^{16} \mathrm{O}$ ratios were normalized by using Vienna Standard Mean Ocean Water compositions (VSMOW,

${ }^{18} \mathrm{O} /{ }^{16} \mathrm{O}=0.0020052$ ), and then corrected for the instrumental mass fractionation factor (IMF) using zircon 91500 as a reference standard with $\delta^{18} \mathrm{O}$ value of $9.9 \%$ (Wiedenbeck et al., 2004). Fifteen measurements of Penglai zircon standard during the course of this study yield a weighted mean of $\delta^{18} \mathrm{O}=5.28 \pm 0.34 \%$ (2SD), which is consistent within errors with the reported value of $5.31 \pm 0.10 \%$ ( $\mathrm{Li}$ et al., 2010b). Zircon oxygen isotopic data are listed in Appendix Table 2.

\subsection{Zircon Lu-Hf isotopes}

In situ zircon Lu-Hf isotopic analysis was carried out on a Neptune multi-collector ICP-MS equipped with a Geolas-193 laser-ablation system at IGGCAS, and the analytical procedures were similar to those described by Wu et al. (2006). Lu-Hf isotopic analyses were obtained on the same zircon grains that were previously analyzed for $\mathrm{U}-\mathrm{Pb}$ and $\mathrm{O}$ isotopes, with ablation pits of $63 \mu \mathrm{m}$ in diameter, ablation time of 26 seconds, repetition rate of $10 \mathrm{~Hz}$, and laser beam energy density of $10 \mathrm{~J} / \mathrm{cm}^{2}$. During laser ablation analyses, the isobaric interference of ${ }^{176} \mathrm{Lu}$ on ${ }^{176} \mathrm{Lu} \mathrm{Hf}$ is negligible due to extremely low ${ }^{176} \mathrm{Lu} \mathrm{Lu} /{ }^{177} \mathrm{Lu} \mathrm{Hf}$ in zircons (mostly $<0.01$ ). Isobaric interference of ${ }^{176} \mathrm{Lu} \mathrm{Yb}$ on ${ }^{176} \mathrm{Lu} \mathrm{Hf}$ is corrected using independent mass bias factors for $\mathrm{Hf}$ and $\mathrm{Yb}$ for correction, since the contribution of ${ }^{176} \mathrm{Lu} \mathrm{Yb}$ to ${ }^{176} \mathrm{Lu} \mathrm{Hf}$ could affect the accuracy of the measured ${ }^{176} \mathrm{Lu} \mathrm{Hf} /{ }^{177} \mathrm{Lu} \mathrm{Hf}$ ratio. The mean ${ }^{173} \mathrm{Lu}$ $\mathrm{Yb} /{ }^{172} \mathrm{Lu} \mathrm{Yb}$ ratio of the individual spots was used to calculate the fractionation coefficient $\left(\beta_{\mathrm{Yb}}\right)$ and the contribution of ${ }^{176} \mathrm{Lu} \mathrm{Yb}$ to ${ }^{176} \mathrm{Lu} \mathrm{Hf}$ by applying ratios of ${ }^{176} \mathrm{Lu} \mathrm{Yb} /{ }^{172} \mathrm{Lu}$ $\mathrm{Yb}=0.5887$ and ${ }^{173} \mathrm{Lu} \mathrm{Yb} /{ }^{172} \mathrm{Lu} \mathrm{Yb}=0.73925$ (Wu et al., 2006). Measured ${ }^{176} \mathrm{Lu} \mathrm{Hf} /{ }^{177} \mathrm{Lu} \mathrm{Hf}$ ratios were normalized to ${ }^{179} \mathrm{Hf} /{ }^{177} \mathrm{Hf}=0.7325$. The determined ${ }^{176} \mathrm{Lu} \mathrm{Hf} /{ }^{177} \mathrm{Lu} \mathrm{Hf}$ value of $0.282497 \pm 0.000018(2 \mathrm{SD}, \mathrm{n}=20)$ for zircon standard Mud Tank during the course of this work is in agreement within errors with the recommended value of $0.282507 \pm 0.000006$ by solution MC-ICP-MS measurements after chemical separation (Woodhead and Hergt, 2005). The reported ${ }^{176} \mathrm{Lu} \mathrm{Hf} /{ }^{177} \mathrm{Lu} \mathrm{Hf}$ value is adjusted relative to the Mud Tank standard value of 0.282507, and the results are listed in Appendix Table 2.

Because zircons from the albitite sample ALP3-6.1 have exceptionally high ${ }^{176} \mathrm{Lu} \mathrm{Yb} /{ }^{177} \mathrm{Lu} \mathrm{Hf}$ (>0.3) that would result in inaccurate isobaric interference correction for the measured ${ }^{176} \mathrm{Lu}$ $\mathrm{Hf} /{ }^{177}$ Lu Hf ratio, we carry out solution MC-ICP-MS measurements for two zircon fractions from this sample. After decomposition of zircon grains, the sample solution was split into two parts, ca. 1/3 of the solution was used for determination of $\mathrm{Yb}, \mathrm{Lu}$ and $\mathrm{Hf}$ concentrations, and the remaining 2/3 solution for MC-ICP-MS measurements of ${ }^{176} \mathrm{Lu} \mathrm{Hf} /{ }^{177} \mathrm{Lu} \mathrm{Hf}$ after chemical purification. The procedures for the separation of $\mathrm{Hf}$ from $\mathrm{Zr}$ and REE were similar to those reported by Goolaerts et al. (2004). The determined ${ }^{176} \mathrm{Lu} \mathrm{Hf} /{ }^{177} \mathrm{Lu} \mathrm{Hf}$ value is $0.282172 \pm 0.000010$ ( $2 \mathrm{SE}$ ) for JMC-475 standard during the course of this work. The reported ${ }^{176} \mathrm{Lu} \mathrm{Hf} /{ }^{177} \mathrm{Lu} \mathrm{Hf}$ values were adjusted relative to a JMC- $475{ }^{176} \mathrm{Lu} \mathrm{Hf} /{ }^{177} \mathrm{Lu} \mathrm{Hf}$ ratio 
of 0.282160 . The Lu-Hf isotopic data obtained by solution MC-ICP-MS measurements is presented in Appendix Table 2.

\section{Analytical results}

\subsection{Zircon $\mathrm{U}-\mathrm{Pb}$ age}

\subsubsection{Troctolite sample ALP3-6.3}

Zircons from this sample are transparent, $50-100 \mu \mathrm{m}$ in length, and have aspect ratios of $\sim 1: 1$ to 2:1. In CL images they are quite homogeneous, with weak, broad zonings (Fig. 2). Fifteen analyses were conducted on 15 zircons during a single analytical session (Appendix Table 1). These zircons have moderate $\mathrm{U}(70-509 \mathrm{ppm})$ and Th (47-421 ppm) contents, and Th/U ratios between 0.51 and 1.38. Common $\mathrm{Pb}$ is low; value for $f_{206}$ (the proportion of common ${ }^{206} \mathrm{~Pb}$ in total measured ${ }^{206} \mathrm{~Pb}$ ) is mostly lower than $1.0 \%$, apart from two analyses (spots 5 and 6 ) that have slightly higher $f_{206}$ value of $1.2-1.5 \%$. All the measured $\mathrm{Pb} / \mathrm{U}$ ratios are concordant within analytical errors, yielding a Concordia age of $165 \pm 1 \mathrm{Ma}(2 \sigma$, MSWD of concordance $=0.01)($ Fig. 2). This age is interpreted as the best estimate of crystallization age of the troctolite.
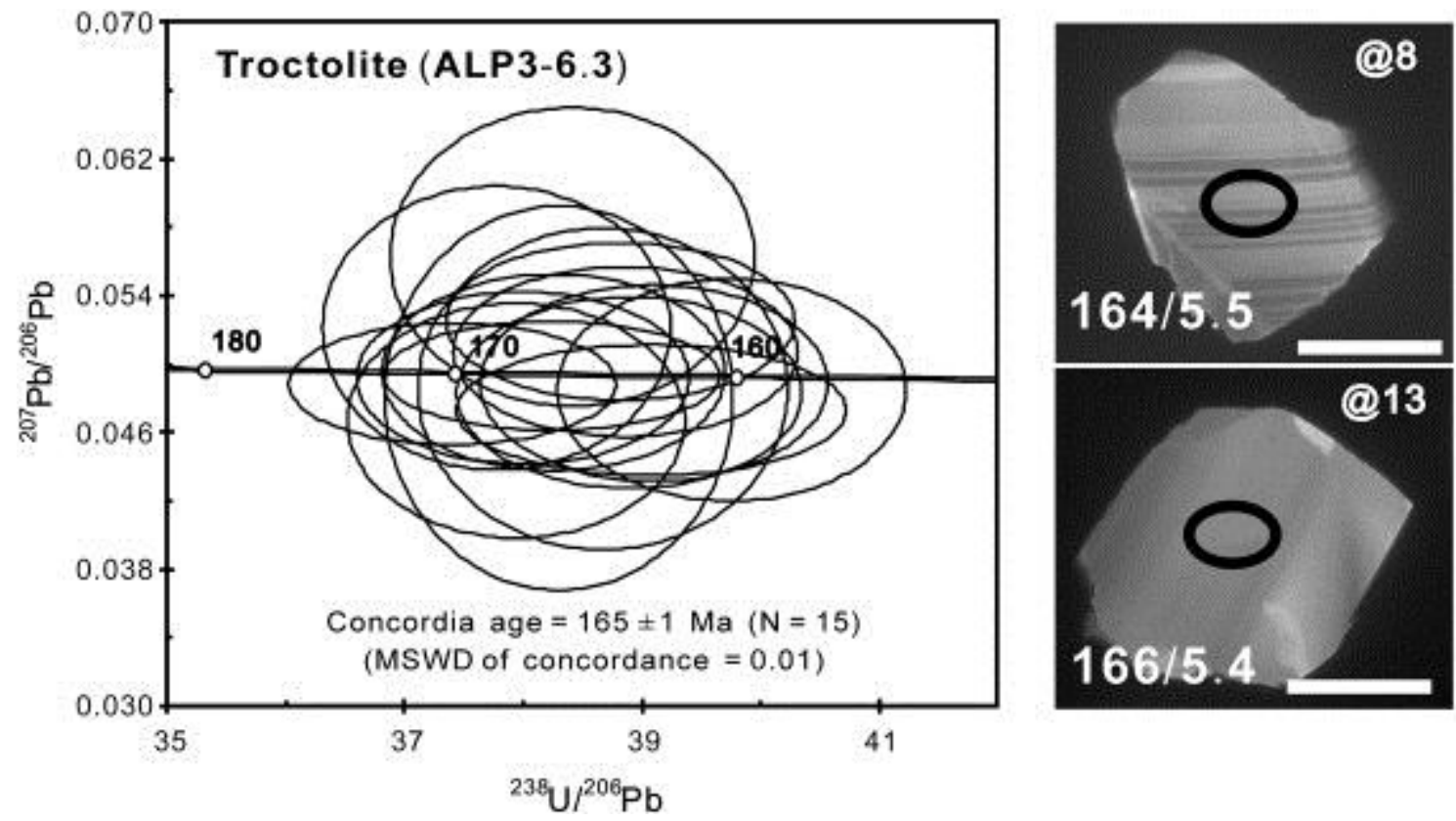

Fig. 2. : U-Pb Concordia diagram for zircons from troctolite sample ALP3-6.3 and CL images for representative zircons. The ellipses in the CL images represent the spots of SIMS U-Pb and $\mathrm{O}$ isotope analyses. The numbers on the left and right are the $\mathrm{U}-\mathrm{Pb}$ dates $(\mathrm{Ma})$ and $\delta^{18} \mathrm{O}$ values, respectively. The white bars are $50 \mu \mathrm{m}$ in length for scale.

\subsubsection{Albitite sample ALP3-6.1}

Zircons are semi-transparent, stubby, $80-150 \mu \mathrm{m}$ in length, and have aspect ratios of $\sim 1: 1$ to 1.5:1. Microfractures are visible in most zircons. In CL images most zircons are characterized by magmatic concentric zonings, associated with, more or less, chaotic/botryoidal domains (Fig. 3A) that are most likely attributed to alteration (Corfu et al., 2003 and Grimes et al., 
2011). Twenty-one analyses were conducted on 21 zircons during a single analytical session (Appendix Table 1). They have moderate U (66-399 ppm) and Th (19-253 ppm) contents, with $\mathrm{Th} / \mathrm{U}$ ratios between 0.20 and 0.94 . Common $\mathrm{Pb}$ is highly variable, with value of $f_{206}$ ranging from $0.16 \%$ to $25.6 \%$. The common $\mathrm{Pb}$-uncorrected ${ }^{206} \mathrm{~Pb} /{ }^{238} \mathrm{U}$ and ${ }^{207} \mathrm{~Pb} /{ }^{206} \mathrm{~Pb}$ ratios define a discordia line on the inverse (Tera-Wasserburg) U-Pb concordia plot (Fig. 3A), with a lower-intercept age of $165 \pm 2 \mathrm{Ma}(2 \sigma, \mathrm{MSWD}=1.3)$. It is noteworthy that nine of twentyone analyses are conducted on the altered zircon domains, providing imprecise ${ }^{206} \mathrm{~Pb} /{ }^{238} \mathrm{U}$ dates ranging from $163 \mathrm{Ma}$ to $184 \mathrm{Ma}$, with uncertainties up to $\pm 16 \mathrm{Ma}(1 \sigma)$ (Appendix Table 1), due to high proportion (3.45-25.6\%) of common $\mathrm{Pb}$. The remaining twelve analyses are made on the least-altered domains (Fig. 3B) that are relatively low in common $\mathrm{Pb}\left(f_{206}\right.$ value $=0.16-2.49 \%$ ). Their $\mathrm{Pb} / \mathrm{U}$ ratios are concordant within analytical errors, yielding a $\mathrm{U}-$ $\mathrm{Pb}$ Concordia age of $165 \pm 2 \mathrm{Ma}(2 \sigma, \mathrm{MSWD}$ of concordance $=0.53)$ (Fig. 3B). We interpret the age of $165 \pm 2 \mathrm{Ma}$ as the best estimate of the timing of crystallization of albitite sample ALP3-6.1. 

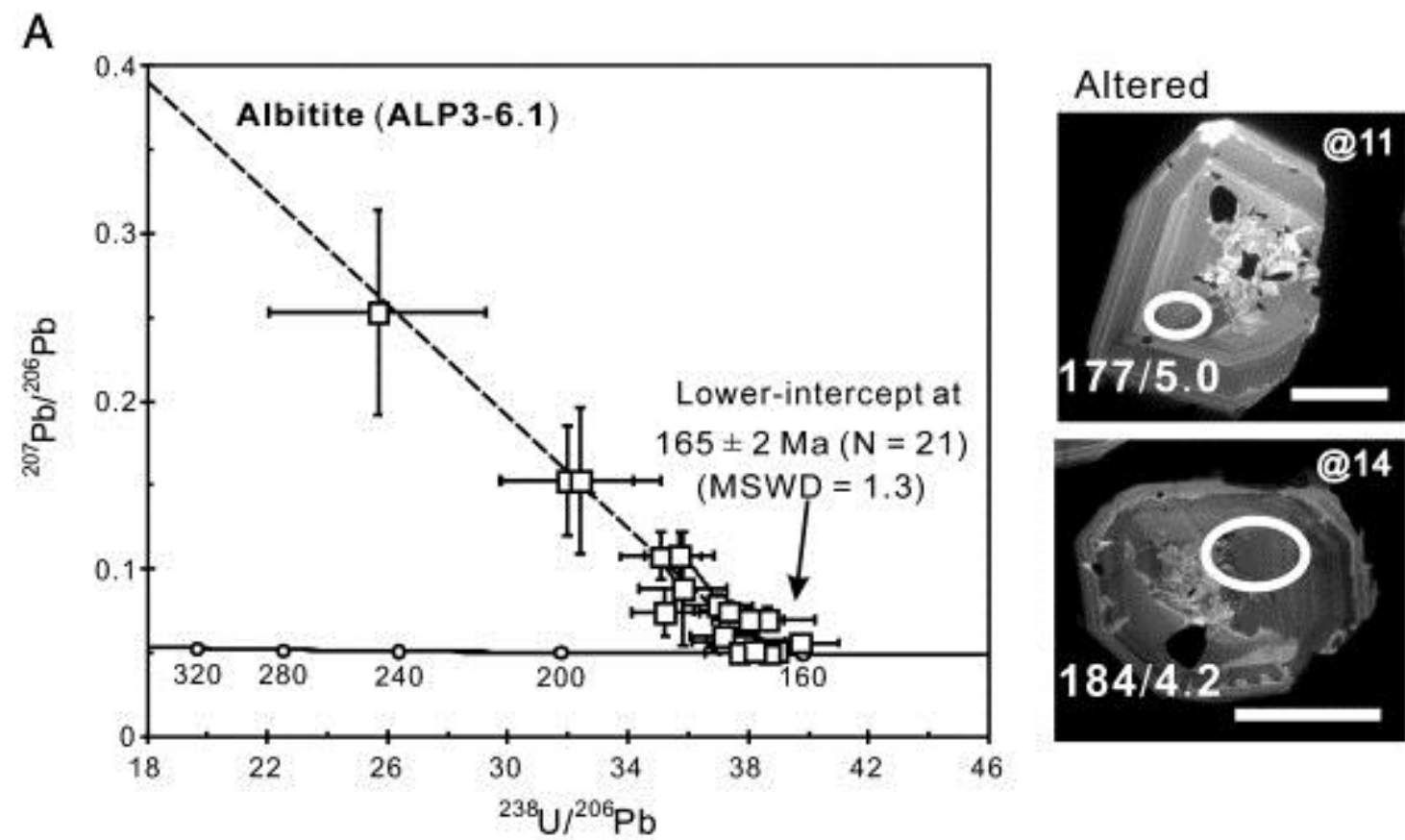

B

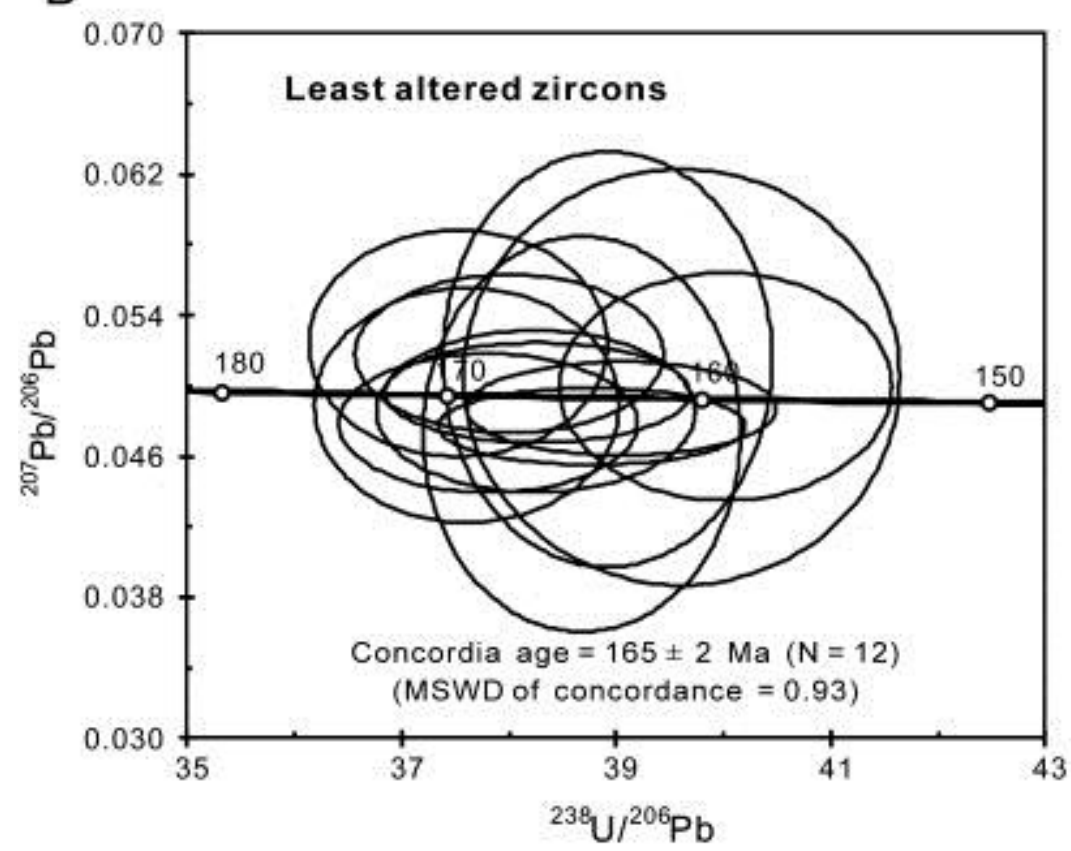

Least-altered
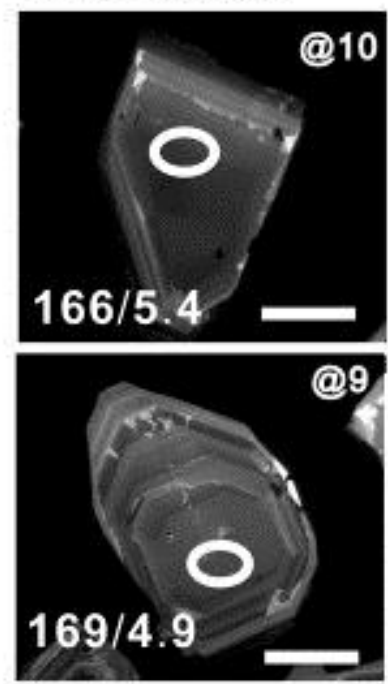

Fig. 3. : U-Pb Concordia diagram for zircons from albitite sample ALP3-6.1 and CL images for representative zircons. (A) All twenty-one analyses; (B) twelve analyses for the leastaltered zircons that are shown are low in common $\mathrm{Pb}$. The ellipses in the $\mathrm{CL}$ images represent the spots of SIMS U-Pb and $\mathrm{O}$ isotope analyses. The numbers on the left and right are the $\mathrm{U}-$ $\mathrm{Pb}$ dates (Ma) and $\delta^{18} \mathrm{O}$ values, respectively. The white bars are $50 \mu \mathrm{m}$ in length for scale.

\subsection{In situ zircon O-Hf isotopes}

In situ $\mathrm{O}-\mathrm{Hf}$ isotopic measurements are conducted on fifteen zircons from the troctolite sample ALP3-6.3. Values of the measured $\delta^{18} \mathrm{O}_{\text {zir }}$ are between 5.1\%o to 5.8\%o (Appendix Table 2), forming a Gaussian distribution. Thus, this troctolite is homogeneous in oxygen 


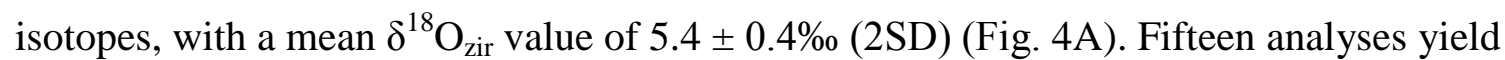
${ }^{176} \mathrm{Yb} /{ }^{177} \mathrm{Hf}$ ratios between 0.023 and 0.117 (Appendix Table 2), which are reasonably low for accurate isobaric interference correction. The analyses give fairly homogeneous ${ }^{176} \mathrm{Hf} /{ }^{177} \mathrm{Hf}$ ratios between 0.283015 and 0.283079 (Appendix Table 2), with an average of $0.283058 \pm 0.000030(2 \mathrm{SD})$, corresponding to $\varepsilon \mathrm{Hf}(\mathrm{t})=+13.5 \pm 1.0(2 \mathrm{SD})$. In order to confirm the LA-MC-ICPMS analyses, we conduct on solution MC-ICP-MS measurement for one zircon fraction after decomposition of zircon grains and chemical purification (Appendix Table 2). The solution analysis yields ${ }^{176} \mathrm{Yb} /{ }^{177} \mathrm{Hf}=0.0614$ and

${ }^{176} \mathrm{Hf} /{ }^{177} \mathrm{Hf}=0.283061 \pm 0.000005(2 \mathrm{SE})$. The calculated $\varepsilon \mathrm{Hf}(\mathrm{t})$ is +13.7 , which is in good agreement within errors with the average $(+13.5 \pm 1.0)$ of LA-MC-ICPMS analyses.
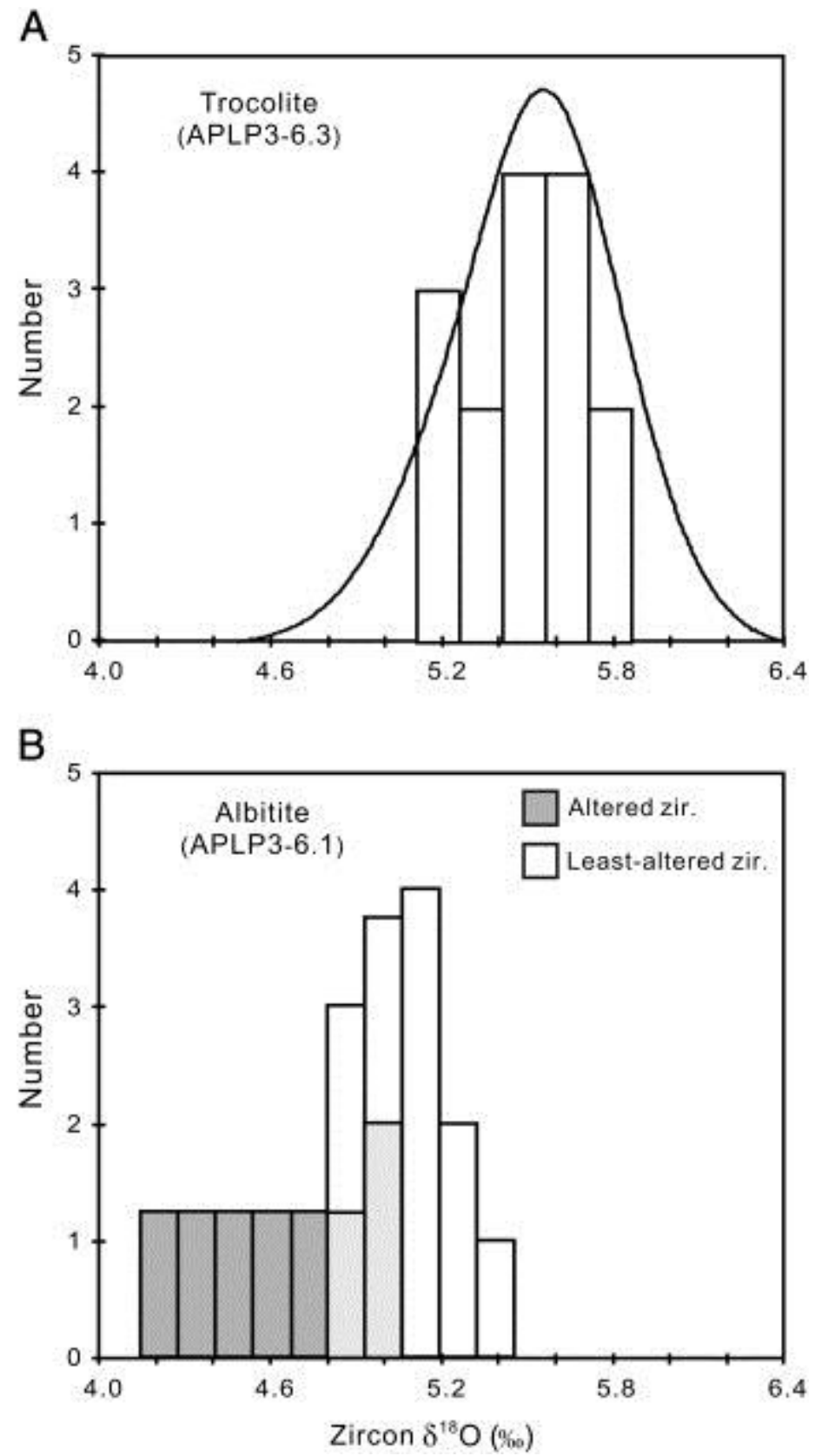

Fig. 4. : Histograms of zircon $\delta^{18} \mathrm{O}$ values for the troctolite (ALP3-6.3) and albitite (ALP36.1) samples. 
Twenty-one zircons from the albitite sample ALP3-6.1 were analyzed for oxygen isotopes. The measured $\delta^{18} \mathrm{O}_{\text {zir }}$ values range from $4.2 \%$ to $5.4 \%$ (Fig. 4B). It is noted, despite being indistinguishable within analytical errors, the altered zircon domains have slightly lower $\delta^{18} \mathrm{O}_{\text {zir }}$ values between $4.2 \%$ to $5.0 \%$ (averaging at $4.7 \pm 0.6 \%$, 2SD) than the least-altered domains that give $\delta^{18} \mathrm{O}_{\mathrm{zir}}$ values between $4.8 \%$ to $5.4 \%$ (averaging at $5.1 \pm 0.4 \%$, 2SD). Overall, the measured $\delta^{18} \mathrm{O}_{\text {zir }}$ values for the troctolite zircons and the least-altered zircon domains from the albitite are consistent within analytical uncertainty with those of igneous zircons from the Mid-Atlantic and Southwest Indian Ridges gabbros, norites, and plagiogranites of modern oceanic crust $(5.3 \pm 0.8 \%$, Cavosie et al., 2009; $5.2 \pm 0.5 \%$, Grimes et al., 2011) and with igneous zircons in high-temperature equilibrium with primitive magma compositions of the mantle $(5.3 \pm 0.6 \%$, Valley et al., 1998, Valley et al., 2005 and Valley, 2003). These albitite zircons have exceptionally high ${ }^{176} \mathrm{Yb} /{ }^{177} \mathrm{Hf}$ ratios between 0.320 and 0.861 (Appendix Table 2) and highly variable ${ }^{176} \mathrm{Hf} /{ }^{177} \mathrm{Hf}$ ratios between 0.283139 and 0.283547. The measured ${ }^{176} \mathrm{Hf} /{ }^{177} \mathrm{Hf}$ ratios, corresponding to $\varepsilon \mathrm{Hf}(\mathrm{t})=+15.6$ to +28.9 , are not only much higher than those of troctolite sample ALP3-6.3, but also correlated positively with the measured ${ }^{176} \mathrm{Yb} /{ }^{177} \mathrm{Hf}$ ratios (not shown). Such anomalously high ${ }^{176} \mathrm{Hf} /{ }^{177} \mathrm{Hf}$ ratios are most likely attributed to inaccurate isobaric interference correction of ${ }^{176} \mathrm{Yb}$ on ${ }^{176} \mathrm{Hf}$. To clarify this, we conducted solution MC-ICP-MS measurements for two zircon fractions after decomposition of zircon grains and chemical purification. These two zircon fractions yield the measured ${ }^{176} \mathrm{Yb} /{ }^{177} \mathrm{Hf}=0.1080$ and 0.3216 and ${ }^{176} \mathrm{Hf} /{ }^{177} \mathrm{Hf}=0.283060 \pm 0.000009$ and $0.283064 \pm 0.000007$ (2SE), respectively (Appendix Table 2). The calculated $\varepsilon \mathrm{Hf}(\mathrm{t})$ values are between +13.5 and +13.0 , consistent within uncertainty with the average of the troctolite zircons $(+13.5 \pm 1.0)$.

\section{Discussion}

\subsection{Formation age for the Chenaillet ocean-floor sequence}

Costa and Caby (2001) and Chalot-Prat et al. (2003) carried out systematic isotopic age determinations for various rock types of the Chenaillet Ophiolite. They reported $\mathrm{Sm}-\mathrm{Nd}$ whole-rock isochron ages of $198 \pm 22 \mathrm{Ma}$ (Costa and Caby, 2001) and $142 \pm 23 \mathrm{Ma}$ (ChalotPrat et al., 2003) for the gabbros, and an ID-TIMS U-Pb zircon age of $156 \pm 3 \mathrm{Ma}$ and $148 \pm 2 \mathrm{Ma}$ for a leucodioritic vein and an albitite lens (Costa and Caby, 2001), respectively. These $\mathrm{Sm}-\mathrm{Nd}$ and $\mathrm{U}-\mathrm{Pb}$ zircon ages were interpreted as the timing of crystallization of the dated rocks. These results implied a multi-stage magmatic process that occurred over $\sim 30$ 50 m.y., which is unusual for true oceanic sequences.

However, Manatschal et al. (2011) questioned the validity of the Sm-Nd isochron age of $198 \pm 22 \mathrm{Ma}$ for the gabbros, because (1) this $\mathrm{Sm}-\mathrm{Nd}$ age is clearly older than the $\mathrm{U}-\mathrm{Pb}$ age of $156 \pm 3 \mathrm{Ma}$ for the leucodiorites that are thought to be genetically related with the gabbros (Desmurs et al., 2002), and (2) the Sm-Nd age of $198 \pm 22$ Ma for the Chenaillet gabbros would invoke their emplacement during continental rifting, prior to first mantle exhumation at 165-160 Ma in the Piemont-Liguria domain (Manatschal and Müntener, 2009). In addition, we noted that five zircon fractions from a leucodiorite sample (MG3511) reported by Costa and Caby (2001) are variably discordant in U-Pb isotopes. While four of the five analyzed fractions yield an average $\mathrm{U}-\mathrm{Pb}$ age of $156 \pm 3 \mathrm{Ma}$, the fifth fraction gives significant older $\mathrm{U}-\mathrm{Pb}$ age of $\sim 170 \mathrm{Ma}$. This older zircon fraction was interpreted by the authors as inheritance. However it is quite unusual that such a significant portion $(\sim 20 \%)$ of inherited 
zircons was present during the formation of the diorite. While the $\mathrm{U}-\mathrm{Pb}$ age of $148 \pm 2 \mathrm{Ma}$ for the albitite (Costa and Caby, 2001) is consistent within errors with the Sm-Nd isochron date of $142 \pm 23 \mathrm{Ma}$ (Chalot-Prat et al., 2003), it is 30 to $50 \mathrm{~m}$.y. and $\sim 3$ to $13 \mathrm{~m}$.y. younger than the U-Pb ages for the gabbro and leucodiorite (Costa and Caby, 2001), respectively. Costa and Caby (2001) and Manatschal et al., (2011) interpreted that the albitites might correspond to a late, possibly an off-axis magmatic event associated with the very last stage of oceanic deformation, whereas others considered that the albitites might represent highly evolved liquids differentiated from a gabbroic or dioritic magma (Bertrand et al., 1987, Caby, 1995 and Desmurs et al., 2002).

Our new SIMS U-Pb zircon dating results demonstrate that the troctolite and albitite within the Chenaillet Ophiolite crystallized synchronously at 165 Ma. Zircon morphology and internal structure of the troctolite (Fig. 2) are well consistent with those of zircons crystallized from mafic magmas (Corfu et al., 2003). Furthermore, troctolite zircons give typical mantlelike $\delta^{18} \mathrm{O}(5.4 \pm 0.4 \%$ o $)$ and highly positive zircon $\varepsilon \mathrm{Hf}(\mathrm{t})(+13.5 \pm 1.0)$, suggesting crystallization from magmas that were produced by partial melting of a depleted, MORB-like mantle.

Zircons from the albitite sample ALP3-6.1 have more complex internal textures than those from the troctolite; they mostly show microfracture and alteration to varying degrees (Fig. 3). Despite careful selection of the targeting domains for SIMS dating at a scale of $20 \times 30 \mu \mathrm{m}$, nine of the twenty-one analyses still have variably high proportion (3.45-25.6\%) of common $\mathrm{Pb}$ as a result of alteration and/or metamictization. To our knowledge, such altered zircons are difficult to be precisely dated by using conventional ID-TIMS method that requires a few milligrams of zircons for analysis. Similar to our imprecise dating results for the altered zircon domains by SIMS, the ID-TIMS zircon U-Pb analyses of the albitite sample MG542 also give high proportion (18-27\%) of common $\mathrm{Pb}$ (Costa and Caby, 2001), making the reported $\mathrm{U}-\mathrm{Pb}$ age of $148 \pm 2 \mathrm{Ma}$ problematic. Contrarily, taking the advantage of SIMS microanalytical technique, we are able to precisely date the albitites by targeting zircon domains that show weak and/or negligible alteration at a small scale of $20 \times 30 \mu \mathrm{m}$. Thus, our new SIMS U-Pb zircon dating result of $165 \pm 2 \mathrm{Ma}$ constrained by 12 analyses of the leastaltered zircon domains is reliable, providing the best estimate of the crystallization age of the albitite.

Troctolites and albitites bracket the intrusive magmatism of the Chenaillet Ophiolite. Our new SIMS zircon $\mathrm{U}-\mathrm{Pb}$ dating results indicate that these intrusive rocks are coeval, placing a robust constraint on the formation age of $\sim 165 \mathrm{Ma}$ for the Chenaillet Ophiolite.

\subsection{Constraints on the albitite genesis}

Plagiogranites, referred collectively to the suite of felsic plutonic rocks (including diorite, quartz diorite, tonalite, trondjhemite and albitite/anorthosite) found in modern ocean crust and ophiolites (e.g.Coleman and Donato, 1979), usually formed as the most differentiated and latest-stage magmas in ocean crust. Despite volumetrically minor, the genesis of oceanic plagiogranites is controversial, with different processes being involved, including (1) extreme fractional crystallization of MORB, (2) liquid immiscibility with Fe-enriched tholeiitic melts, and (3) hydrous partial melting of oceanic gabbros (see review of Koepke et al., 2007). In contrast to the Platta ophiolite in the Central Alps where the albitites are in close association with ferrogabbros ( Desmurs et al., 2001 and Schaltegger et al., 2002), the Chenaillet albitites do not show direct relationships with the ferrogabbros in the field. Process 1 and process 3 
have been proposed for diorites and albitites from the Chenaillet Ophiolite (e.g., Bertrand et al., 1987, Caby, 1995 and Costa and Caby, 2001). It should be noted that element geochemistry and radiogenic isotopic systems such as $\mathrm{Sm}-\mathrm{Nd}$ and $\mathrm{Lu}-\mathrm{Hf}$ in which the parental isotopes have half-lives exceeding billions of years are not able to clearly distinguish the process 1 from the process 3 .

Alternatively, zircon oxygen isotopes of the plagiogranites could provide an effective approach to this problem. This is because (1) zircons, which are usually retentive of the magmatic oxygen isotopes, in equilibrium with mantle-derived magmas have very consistent

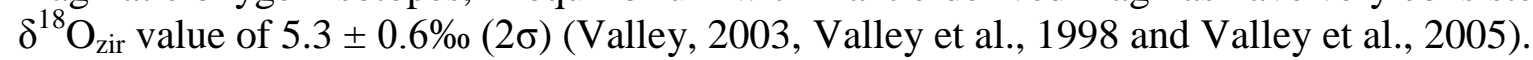
This mantle zircon value is insensitive to magmatic differentiation, because the increase in bulk rock $\delta^{18} \mathrm{O}$ value is compensated by an increase in zircon/liquid $\delta^{18} \mathrm{O}$ fractionation, (2) zircons are highly resistant to alteration except for extreme cases (e.g., hydrothermal alteration and metamictization), and commonly preserve primary magmatic $\delta^{18} \mathrm{O}$ values ( Grimes et al., 2011, Page et al., 2007, Valley, 2003 and Valley et al., 2005). Identification of altered and/or metamict zircons are readily feasible by combined determination of zircon internal textures in CL images and correlation of age concordance, $\mathrm{Pb}$-loss and/or common- $\mathrm{Pb}$ proportion to $\delta^{18} \mathrm{O}_{\text {zir }}$ value (e.g., Booth et al., 2005 and Corfu et al., 2003), and (3) hydrothermal alteration of oceanic gabbros by infiltration of seawater leads to $\delta^{18} \mathrm{O}$ value higher than $6 \%$ at temperature below $200-250{ }^{\circ} \mathrm{C}$, but lower than $5 \%$ obove $200-250{ }^{\circ} \mathrm{C}$ (e.g., Alt and Bach, 2006, Bindeman et al., 2005 and Muehlenbachs, 1986). Thus, plagiogranites formed by the process 1 and 3 would have significantly different $\delta^{18} \mathrm{O}_{\mathrm{zir}}$ values, i.e., plagiogranites formed by process 1 should have mantle-like $\delta^{18} \mathrm{O}_{\text {zir values, whereas, those }}$ formed by process 3 would have $\delta^{18} \mathrm{O}_{\text {zir }}$ values either lower or higher than the mantle values depending on temperature of hydrothermal alteration of the gabbro protoliths.

Zircons from the albitite sample ALP3-6.1 show features of variable alteration, suggesting that the albitite is overprinted by subsolidus hydrothermal alteration. This is consistent with the pseudomorphosed amphibole into secondary tremolite/actinolite. Nine altered zircons

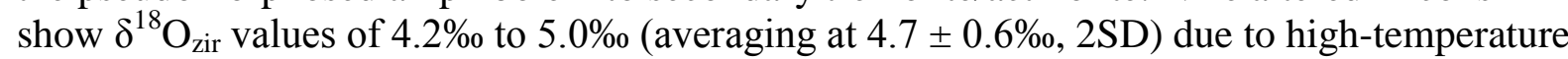
alteration. Similar phenomenon has been reported for the altered ocean-crust zircons that give $\delta^{18} \mathrm{O}_{\text {zir }}$ values from 0.0 to 5.0\%o (Fu et al., 2012; Grimes et al., 2011). On the contrary, the least-altered zircon domains from the albitite give a mean $\delta^{18} \mathrm{O}_{\mathrm{zir}}$ value of $5.1 \pm 0.4 \%$ (2SD) that is well consistent with the average $\delta^{18} \mathrm{O}_{\text {zir }}$ value of $5.2 \pm 0.5 \%$ determined for 107 normal magmatic zircons from plagiogranites (Grimes et al., 2011), and also indistinguishable within uncertainties from the average value $(5.4 \pm 0.4 \%$ o $)$ for the troctolite sample ALP3-6.3 and the range of $5.3 \pm 0.6 \%$ observed for zircons in high-temperature equilibrium with primitive mantle (Valley, 2003, Valley et al., 1998 and Valley et al., 2005). Therefore, the least-altered albitite zircons do not show any detectable seawater signature, indicating that the albitite should have formed prior to significant interactions between the ocean-crust and seawater. In other words, the albitite is most likely generated by the aforementioned process 1 . If the albitites were formed by hydrous partial melting of oceanic gabbros (i.e. the process 3 ), their zircon oxygen isotopic features request that the gabbros should preserve MORB-like $\delta^{18} \mathrm{O}$ value at the time of melting. This would invoke very low degrees of hydrothermal alteration of the protolith gabbros prior to melting and zircon crystallization. In consideration of the synchronous crystallization at $\sim 165 \mathrm{Ma}$ and consistent zircon O-Hf isotopes of the troctolite and albitite, we suggest that the troctolites and albitites are most likely cogenetic, and the albitites were formed by extreme fractional crystallization from a gabbroic magma (Bertrand et al., 1987). This interpretation is consistent with the identical zircon $\varepsilon \mathrm{Hf}(\mathrm{T})$ values for the 
troctolite $(+13.5 \pm 1.0)$ and albite $(+13.2 \pm 0.2)$ and is also similar to the processes described from other Alpine ophiolites ( Desmurs et al., 2002 and Schaltegger et al., 2002).

While the process 2 (liquid immiscibility with Fe-enriched tholeiitic melts) is not favoured for the Chenaillet albitites in terms of the field relationship between the albitites and ferrogabbros, our isotopic study alone could not entirely rule out this possibility. Examination of this possibility awaits further petrological and geochemical investigations.

\subsection{Implications for age and nature of the crust and width of the Piemont-Liguria domain}

The discovery of symmetric seafloor spreading recorded by magnetic anomalies in oceanic domains enabled to propose a simple relationship between a location in the ocean, its distance from the mid ocean ridge and its spreading rate. Applying this concept to ophiolites enables to determine a location relative to the edge of the former ocean assuming that age of accretion, i.e. age of the formation of the mafic crust, and continental breakup are known and off-axis magmatic activity can be excluded. Based on this concept, ages obtained from ophiolites can be used to restore ancient oceanic domains.

In the case of the Alpine Tethys, numerous radiometric data have been reported since 1980's, providing a $~ 30 \mathrm{~m} . \mathrm{y}$. life span for the formation of the Piemont-Liguria oceanic basin (e.g., Costa and Caby, 2001). A compilation of zircon $\mathrm{U}-\mathrm{Pb}$ age data from the ophiolitic gabbros and plagiogranites from the Central and Western Alps, Liguria and Corsica is presented in Fig. 5. Sm-Nd isochron and $\mathrm{Ar} / \mathrm{Ar}$ or $\mathrm{K}-\mathrm{Ar}$ age data are not included, because they are either imprecise or susceptible to Alpine overprinting, and do therefore not necessarily date the age of accretion of a given piece of ophiolite.
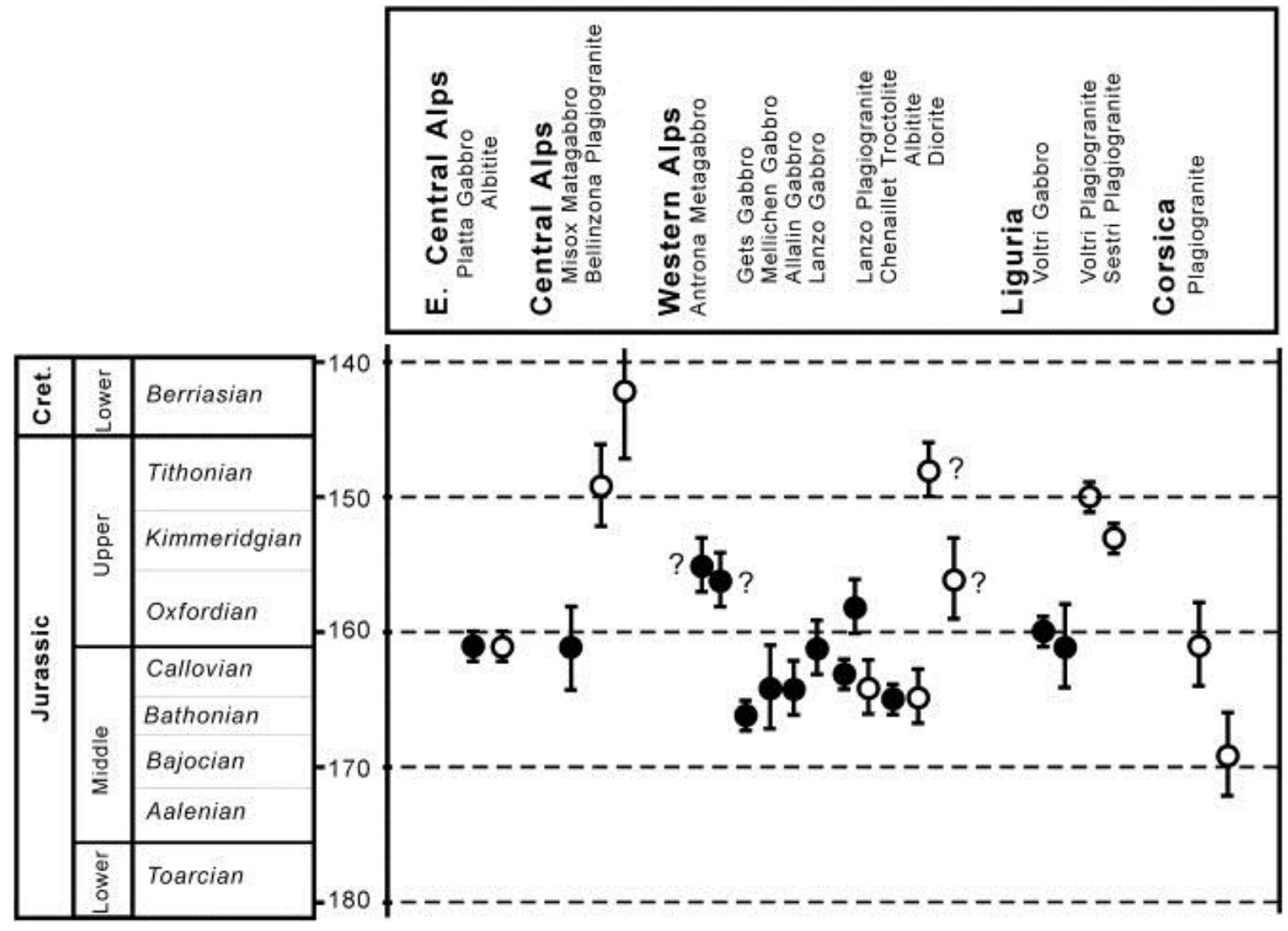
Fig. 5. : Compilation of $\mathrm{U}-\mathrm{Pb}$ age determinations for mafic (solid circles) and plagiogranitic (open circles) rocks from the Piemont-Liguria ocean. Data sources: Bill et al. (1997), Borsi et al. (1996), Costa and Caby (2001), Kaczmarek et al. (2008), Liati et al. (2005), Ohnenstetter et al. (1981), Rossi et al. (2002), Rubatto and Scambelluri (2003), Rubatto et al. (1998), Rubatto et al. (2008), Schaltegger et al. (2002), Stucki et al. (2003); this study.

The U-Pb zircon dates for the plagiogranites are highly variable ranging from 142 to $169 \mathrm{Ma}$ (Borsi et al., 1996, Costa and Caby, 2001, Ohnenstetter et al., 1981, Rossi et al., 2002, Rubatto and Scambelluri, 2003, Rubatto et al., 2008, Schaltegger et al., 2002 and Stucki et al., 2003). While the plagiogranites from the Platta, Lanzo and Chenaillet Ophiolites are dated at 161-165 Ma, coeval with the co-exiting MOR gabbros (Rubatto et al., 2008 and Schaltegger et al., 2002; this study), others are either poorly dated or differ in age significantly from the co-existing gabbros. Because most plagiogranite zircons are subject to oceanic alteration and/or high-pressure metamorphism, their crystallization ages await further investigations.

In contrast to the highly variable age data for the plagiogranite, all $\mathrm{U}-\mathrm{Pb}$ zircon ages for the ophiolitic gabbros are between 166 and $155 \mathrm{Ma}$ (Bill et al., 1997, Kaczmarek et al., 2008, Liati et al., 2005, Rubatto and Scambelluri, 2003 and Rubatto et al., 1998Schaltegger et al., 2002; this study). It is noted that two metagabbros from Antrona gave younger $\mathrm{U}-\mathrm{Pb}$ ages of 155-156 Ma (Liati et al., 2005) than others from the Western Alps. Zircons from these two metagabbros are strongly affected by the Alpine overprint, and the "co-magmatic domains" have SHRIMP ${ }^{206} \mathrm{~Pb} /{ }^{238} \mathrm{U}$ dates vary from 129 to $163 \mathrm{Ma}$ (Liati et al., 2005). Average of such highly variable dates could not give a statistically meaningful age. We consider that the maximum ${ }^{206} \mathrm{~Pb} /{ }^{238} \mathrm{U}$ dates of $160 \pm 3 \mathrm{Ma}$ and $163 \pm 2 \mathrm{Ma}(1 \sigma)$, which might have been subjected to the least radiogenic $\mathrm{Pb}$ loss, possibly provide the lower age limits for the two metagabbros, consistent with the $\mathrm{U}-\mathrm{Pb}$ zircon ages for the other gabbros from the Western Alps. Apart from the two Antrona metagabbros, all other ophiolitic gabbros have crystallization ages clustering around 158-166 Ma. These consistent $\mathrm{U}-\mathrm{Pb}$ age data thus suggest a life span of $\leq 8 \mathrm{~m}$.y. for the formation of the Piemont-Liguria oceanic basin, rather than $\mathrm{a} \sim 30 \mathrm{~m}$.y. life span as previously thought. Taking into account an external age uncertainty of about $\pm 2-3$ Ma for these middle Jurassic rocks by SIMS and/or LA-ICPMS U$\mathrm{Pb}$ zircon dating technique, the maximum life span documented by the ophiolitic gabbros is about $11 \mathrm{~m}$.y. This short time range also corresponds to the ages of the Radiolarian cherts that are the oldest sediments overlying the ophiolites (Bill et al., 2001). Assuming spreading velocities that are $<3 \mathrm{~cm} / \mathrm{yr}$ full rate, commonly considered as maximum values for magmapoor MOR sequences corresponding to those described from the Alps (Cannat et al., 2009), the maximum width to the paleo-ocean floor would have been in the order of $300 \mathrm{~km}$ (Fig. 6). This width also corresponds to the length of the slab imaged beneath the Alps and commonly interpreted as the subducted remnant of the former Piemont-Liguria ocean (Kissling et al., 2006). The available age data also do not show significant geographic difference for gabbros across the Piemont-Liguria oceanic basin. For instance, the $\sim 165 \mathrm{Ma}$ Chenaillet Ophiolite, is nearly synchronous with gabbros from the $\sim 166$ Ma Gets and $\sim 161$ Ma Platta nappes that intruded into subcontinental mantle and are associated with continent derived extensional allochthons, characteristic for ocean-continent transition zone (Bill et al., 1997, Kaczmarek et al., 2008 and Manatschal and Müntener, 2009Schaltegger et al., 2002). Therefore, the Chenaillet Ophiolite may not represent a piece of "mature" oceanic crust, but rather represent a remnant of embryonic oceanic crust surrounded by a hyper-extended domain comparable to the present northern Red Sea (Manatschal and Müntener, 2009). However, such embryonic oceanic domains are not necessarily symmetric and the processes controlling their formation 
are yet little understood. The study of the Chenaillet Ophiolite shows that this domain was characterized by the scarcity of mafic plutonic rocks and the occurrence of exhumed mantle, the absence of a sheeted dike complex linking the intrusives with the volcanic pillow lavas, and the occurrence of top-basement detachment faults associated with tectono-sedimentary breccias, also referred to as oceanic core complexes (e.g.Manatschal et al., 2011).
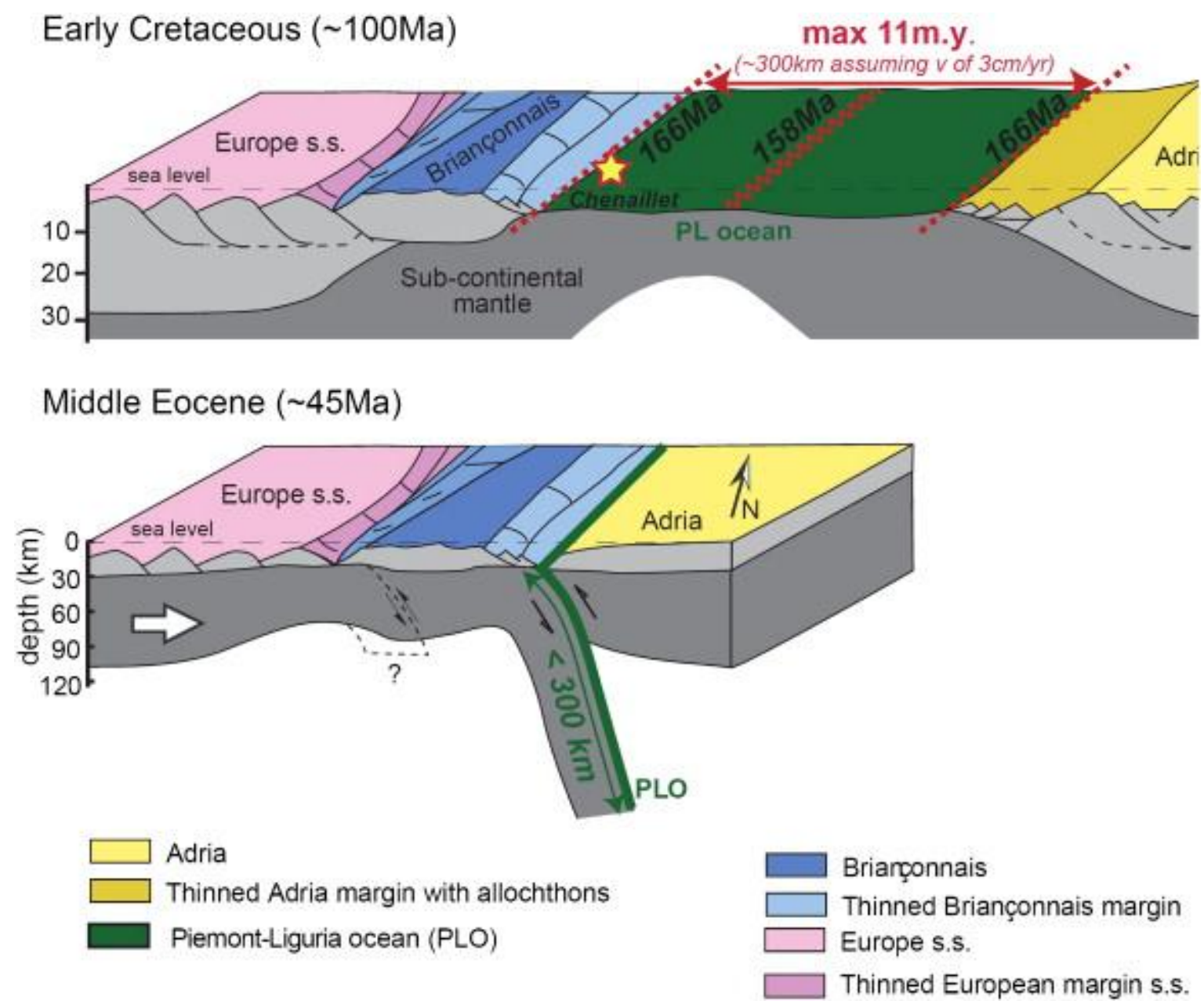

Fig. 6. : Conceptual 3D model showing the temporal and spatial evolution of the Alpine domain from an embryonic oceanic stage (Early Cretaceous ( $100 \mathrm{Ma})$ ) to the onset of collision (Middle Eocene ( $45 \mathrm{Ma})$. The age of the dated rocks from the Piemont-Liguria domain range between 166 and $158 \mathrm{Ma}$, which gives, including error bars, a maximal duration of seafloor accretion of $11 \mathrm{~m} . \mathrm{y}$. Assuming maximum velocity rates of $3 \mathrm{~cm} / \mathrm{yr}$, corresponding to the upper bound of accretion rates associated with mantle exhumation in modern spreading systems, would result in a maximum width of about $300 \mathrm{~km}$ for the Piemont-Liguria basin. $300 \mathrm{~km}$ corresponds also to the length of the slab observed today beneath the Alps (3D block is modified after Beltrando et al., 2010).

\section{Conclusions}

In conclusion, our new SIMS U-Pb zircon dating results demonstrate that the troctolites and albitites within the Chenaillet Ophiolite crystallized synchronously at $\sim 165 \mathrm{Ma}$. In situ analyses of zircon $\mathrm{O}-\mathrm{Hf}$ isotopes indicate that the troctolites and albitites are cogenetic, the albitites were formed by extreme fractional crystallization from a MOR basaltic magma. Our 
new dating results and compilation of the reliable literature $\mathrm{U}-\mathrm{Pb}$ age data suggest a short life span of less than 11 m.y. for the formation of the Piemont-Liguria oceanic domain with a maximum width in the order of $300 \mathrm{~km}$. The Chenaillet ophiolite may represent a remnant of embryonic oceanic crust.

\section{Acknowledgement}

This study was initiated during a Sino-French joint field excursion to Western Alps organized and led by Profs. J. Charvet, R.X. Zhu, M. Faure and Y. Chen in 2010. We thank Y.Y. Gao and $\mathrm{X}$.Y. Jiang for their assistance in zircon $\mathrm{U}-\mathrm{Pb}$ age and $\mathrm{O}-\mathrm{Hf}$ isotopic analyses, and Françoise Chalot-Prat and Philippe Rossi for their comments which helped to improve the manuscript. This work is supported by the National Natural Science foundation of China (grant 41273070) and the State Key Laboratory of Lithospheric Evolution, IGGCAS.

\section{References}

J.C. Alt, W. Bach

Oxygen isotope composition of a section of lower oceanic crust, ODP Hole 735B

Geochemistry, Geophysics, Geosystem, 7 (2006), p. G12008

M. Beltrando, R. Compagnoni, B. Lombardo

(Ultra-) high-pressure metamorphism and orogenesis: an Alpine perspective

Gondwana Research, 18 (2010), pp. 147-166

J. Bertrand, V. Dietrich, P. Nievergelt, M. Vuagnat

Comparative major and trace element geochemistry of gabbroic and volcanic rock sequences, Montgenèvre ophiolite, Western Alps

Schweizerische Mineralogische und Petrographische Mitteilungen, 67 (1987), pp. 147-169

M. Bill, F. Bussy, M. Cosca, H. Masson, J.C. Hunziker

High-precision $\mathrm{U}-\mathrm{Pb}$ and ${ }^{40} \mathrm{Ar} /{ }^{39} \mathrm{Ar}$ dating of an Alpine ophiolite (Gets nappe, French Alps)

Eclogae Geologicae Helvetiae, 90 (1997), pp. 43-54

M. Bill, L. O'Dogherty, J. Guex, P.O. Baumgartner, H. Masson

Radiolarite ages in Alpine-Mediterranean ophiolites: constraints on the oceanic spreading and the Tethys-Atlantic connection

Geological Society of America Bulletin, 113 (2001), pp. 129-143

I.N. Bindeman, J.M. Eilerb, G.M. Yogodzinski, Y. Tatsumi, C.R. Stern, T.L. Grove, M. Portnyagin, K. Hoernle, L.V. Danyushevsky

Oxygen isotope evidence for slab-derived in modern and ancient subduction zones Earth and Planetary Science Letters, 235 (2005), pp. 480-496

L.P. Black, S.L. Kamo, C.M. Allen, D.W. Davis, J.N. Aleinikoff, J.W. Valley, R. Mundil, I.H. Campbel, R.J. Korsch, I.S. Williams, Chris Foudoulis

Improved ${ }^{206} \mathrm{~Pb} /{ }^{238} \mathrm{U}$ microprobe geochronology by the monitoring of a traceelement-related matrix effect; SHRIMP, ID-TIMS, ELA-ICP-MS and oxygen isotope documentation for a series of zircon standards 
Chemical Geology, 205 (2004), pp. 115-140

A.L. Booth, Y. Kolodny, P. Chamberlain, M. Mcwilliams, A.K. Schmitt, J. Wooden

Oxygen isotopic composition and $\mathrm{U}-\mathrm{Pb}$ discordance in zircon

Geochimica et Cosmochimica Acta, 69 (2005), pp. 4895-4905

L. Borsi, U. Schärer, L. Gaggero, L. Crispini

Age, origin and geodynamic significance of plagiogranites in lherzolites and gabbros of the Piedmont-Ligurian ocean basin

Earth and Planetary Science Letters, 140 (1996), pp. 227-241

R. Caby

Plastic deformation of gabbros in a slow-spreading Mesozoic Ridge: example of the Montgenèvre Ophiolite

R.L.M. Vissers, A. Nicolas (Eds.), Mantle and Lower Crust Exposed in Oceanic Ridges and in Ophiolites, Kluwer Academic Publishers (1995), pp. 123-145

M. Cannat, G. Manatschal, D. Sauter, G. Péron-Pinvidic

Assessing the conditions of continental breakup at magma-poor rifted margins: what can we learn from slow-spreading mid-ocean ridges?

Comptes Rendus Geoscience, 341 (2009), pp. 406-427

A.J. Cavosie, N.T. Kita, J.W. Valley

Mantle oxygen-isotope ratio recorded in magmatic zircon from the Mid-Atlantic Ridge

American Mineralogist, 9 (2009), pp. 926-934

F. Chalot-Prat, J. Ganne, A. Lombard

No significant element transfer from the oceanic plate to the mantle wedge during subduction and exhumation of the Tethys Ocean (western Alps)

Lithos, 69 (2003), pp. 69-103

F. Chalot-Prat

An undeformed ophiolite in the Alps: field and geochemical evidence for a link between volcanism and shallow plate tectonic processes

,in: G.R. Foulger, J.H. Natland, D.C. Presnall, D.L. Anderson (Eds.), Plates, plumes and paradigms, Geological Society of America Special Papers, 388 (2005), pp. $751-780$

Chapelle, B., 1990. La lithosphère océanique de la Téthys ligure. Etude des magmatismes basiques et acides (massifs ophiolitiques du Montgenèvre et de Haute-Ubaye). PhD Thesis, Grenoble, France, 196 pp.

R.G. Coleman, M.M. Donato

Oceanic plagiogranite revisited

F. Barker (Ed.), Trondhjemites, Dacites, and Related Rocks, Elsevier, Amsterdam (1979), pp. 149-167

F. Corfu, J.M. Hanchar, P.W.O. Hoskin, P. Kinny

Atlas of zircon textures 
,in: J.M. Hanchar, P.W.O. Hoskin, J.M. Hanchar, P.W.O. Hoskin (Eds.), Zircon, Reviews in Mineralogy and Geochemistry, 53 (2003), pp. 469-500

S. Costa, R. Caby

Evolution of the Ligurian Tethys in the Western Alps: Sm/Nd and U/Pb geochronology and rare-earth element geochemistry of the Montgenève ophiolite (France)

Chemical Geology, 175 (2001), pp. 449-466

L. Desmurs, G. Manatschal, D. Bernoulli

The Steinmann Trinity revisited: mantle exhumation and magmatism along an ocean-continent transition: the Platta nappe, eastern Switzerland ,in: R.C.L. Wilson, R.B. Whitmarsh, B. Taylor, N. Froitzheim (Eds.), Nonvolcanic rifting of continental margins: a comparison of evidence from land and sea, Geological Society, London, Specical Publications, 187 (2001), pp. 235-266

L. Desmurs, O. Müntener, G. Manatschal

Onset of magmatic accretion within a magma-poor rifted margin: a case study from the Platta ocean-continent transition, eastern Switzerland Contributions to Mineralogy and Petrology, 144 (2002), pp. 365-382

B. Fu, B. Paul, J. Cliff, M. Bröcker, F. Bulle

$\mathrm{O}-\mathrm{Hf}$ isotope constraints on the origin of zircon in high-pressure mélange blocks and associated matrix rocks from Tinos and Syros, Greece

European Journal of Mineralogy, 24 (2012), pp. 277-287

A. Goolaerts, N. Mattielli, J.D. Jong, D. Weis, D. James, J.S. Scoates

$\mathrm{Hf}$ and Lu isotopic reference values for the zircon standard 91500 by MC-ICP-MS Chemical Geology, 206 (2004), pp. 1-9

C.B. Grimes, T. Ushikubo, B.E. John, J.W. Valley

Uniformly mantle-like $\delta^{18} \mathrm{O}$ in zircons from oceanic plagiogranites and gabbros Contributions to Mineralogy and Petrology, 161 (2011), pp. 13-33

M.A. Kaczmarek, O. Müntener, D. Rubatto

Trace element chemistry and U-Pb dating of zircons oceanic gabbros and their relationship with whole rock composition (Lanzo, Italian Alps)

Contributions to Mineralogy and Petrology, 155 (2008), pp. 295-312

E. Kissling, S.M. Schmid, R. Lippisch, J. Ansorge, B. Fügenschuh

Lithosphere structure and tectonic evolution of the Alpine arc: new evidence from high-resolution teleseismic tomography

,in: D. Gee, R.A. Stephenson (Eds.), European lithosphere dynamics, Geological Society, London, Memoirs, 32 (2006), pp. 129-145

J. Koepke, J. Berndt, S.T. Feig, F. Holtz

The formation of $\mathrm{SiO}_{2}$-rich melts within deep oceanic crust by hydrous partial melting of gabbros

Contributions to Mineralogy and Petrology, 153 (2007), pp. 67-84 
M. Lemoine, P. Tricart, G. Boillot

Ultramafic and gabbroic ocean floor of the Ligurian Tethys (Alps, Corsica, Apennines): in search of a genetic model

Geology, 15 (1987), pp. 622-625

A.D. Lewis, J.D. Snewing

The Montgenèvre ophiolite (Hautes-Alpes, France): metamorphism and trace element geochemistry of the volcanic sequence

Chemical Geology, 28 (1980), pp. 291-306

X.H. Li, Y. Liu, Q.L. Li, C.H. Guo, K.R. Chamberlain

Precise determination of Phanerozoic zircon $\mathrm{Pb} / \mathrm{Pb}$ age by multi-collector SIMS without external standardization

Geochemistry, Geophysics, Geosystem, 10 (2009), p. Q04010

X.H. Li, W.X. Li, Q.L. Li, X.C. Wang, Y. Liu, Y.H. Yang

Petrogenesis and tectonic significance of the $850 \mathrm{Ma}$ Gangbian alkaline complex in South China: evidence from in-situ zircon $\mathrm{U}-\mathrm{Pb}$ and $\mathrm{Hf}-\mathrm{O}$ isotopes and wholerock geochemistry

Lithos, 114 (2010), pp. 1-15

X.H. Li, W.G. Long, Q.L. Li, Y. Liu, Y.F. Zheng, Y.H. Yang, K.R. Chamberlain, D.F. Wan, C.H. Guo, X.C. Wang, H. Tao

Penglai zircon megacryst: a potential new working reference for microbeam analysis of $\mathrm{Hf}-\mathrm{O}$ isotopes and $\mathrm{U}-\mathrm{Pb}$ age

Geostandards and Geoanalytical Research, 34 (2010), pp. 117-134

A. Liati, N. Froitzheim, C.M. Fanning

Jurassic ophiolites within the Valais domain of the Western and Central Alps: geochronological evidence for re-rifting of oceanic crust

Contributions to Mineralogy and Petrology, 149 (2005), pp. 446-461

K.R. Ludwig

Users manual for Isoplot/Ex rev. 2.49, Spec. Publ. 1a, Berkeley Geochronology Center, Berkeley, California

(2001)

G. Manatschal, O. Müntener

A type sequence across an ancient magma-poor ocean-continent transition: the example of the western Alpine Tethys ophiolites

Tectonophysics, 473 (2009), pp. 4-19

G. Manatschal, D. Sauter, A.M. Karpoff, E. Masini, G. Mohn, Y. Lagabrielle

The Chenaillet Ophiolite in the French/Italian Alps: an ancient analogue for an Oceanic Core Complex?

Lithos, 124 (2011), pp. 169-184

C. Mével, R. Caby, J.R. Kienast

Amphibolite facies conditions in the oceanic crust: example of amphibolized flaser-gabbro and amphibolites from the Chenaillet ophiolite massif (Hautes Alpes, France) 
Earth and Planetary Science Letters, 39 (1978), pp. 98-108

K. Muehlenbachs

Alteration of the ocean crust and the ${ }^{18} \mathrm{O}$ history of seawater ,in: J.W. Valley, H.P. Taylor, J.R. O'Neil (Eds.), Reviews in mineralogy, 16 (1986), pp. 425-444

M. Ohnenstetter, D. Ohnenstetter, P. Vidal, J. Cornichet, D. Hermitte, J. Mace Crystallization and age of zircon from Corsican ophiolitic albitites: consequences for oceanic expansion in Jurassic times Earth and Planetary Science Letters, 54 (1981), pp. 397-408

F.Z. Page, T. Ushikubo, N.T. Kita, L.R. Riciputi, J.W. Valley

High-precision oxygen isotope analysis of picogram samples reveals $2 \mu \mathrm{m}$ gradients and slow diffusion in zircon American Mineralogist, 92 (2007), pp. 1772-1775

P. Rossi, A. Cocheriea, D. Lahondèrea, C. Mark Fanning

La marge européenne de la Téthys jurassique en Corse: datation de trondhjémites de Balagne et indices de croûte continentale sous le domaine Balano-Ligure Comptes Rendus Geoscience, 334 (2002), pp. 313-322

D. Rubatto, M. Scambelluri

$\mathrm{U}-\mathrm{Pb}$ dating of magmatic zircon and metamorphic baddeleyite in the Ligurian eclogites (Voltri Massif, Western Alps)

Contributions to Mineralogy and Petrology, 146 (2003), pp. 341-355

D. Rubatto, D. Gebauer, M. Fanning

Jurassic formation and Eocene subduction of the Zermatt-Saas-Fee ophiolites: implications for the geodynamic evolution of the Central and Western Alps Contributions to Mineralogy and Petrology, 132 (1998), pp. 269-287

D. Rubatto, O. Müntener, A. Barnhoorn, C.J. Gregory

Dissolution-precipitation of zircon at low-temperature, high-pressure conditions (Lanzo Massif, Italy)

American Mineralogist, 93 (2008), pp. 1519-1529

U. Schaltegger, L. Desmurs, G. Manatschal, O. Müntener, M. Meier, M. Frank, D. Bernoulli

The transition from rifting to seafloor spreading within a magma-poor rifted margin: field and isotopic constraints

Terra Nova, 14 (2002), pp. 156-162

J.S. Stacey, J.D. Kramers

Approximation of terrestrial lead isotope evolution by a two-stage model Earth and Planetary Science Letters, 26 (1975), pp. 207-221

A. Stucki, D. Rubatto, V. Trommsdorff

Mesozoic ophiolite relics in the Southern Steep Belt of the Central Alps

Schweizerische Mineralogische und Petrographische Mitteilungen, 83 (2003), pp. 285-299 
J.W. Valley

Oxygen isotopes in zircon

,in: J.M. Hanchar, P.W.O. Hoskin (Eds.), Zircon, Reviews in Mineralogy and

Geochemistry, 53 (2003), pp. 343-385

J.W. Valley, P.D. Kinny, D.J. Schulze, M.J. Spicuzza

Zircon megacrysts from kimberlite: oxygen isotope variability among mantle melts Contributions to Mineralogy and Petrology, 133 (1998), pp. 1-11

J.W. Valley, J.S. Lackey, A.J. Cavosie, C.C. Clechenko, M.J. Spicuzza, M.A.S. Basei, I.N. Bindeman, V.P. Ferreira, A.N. Sial, E.M. King, W.H. Peck, A.K. Sinha, C.S. Wei 4.4 billion years of crustal maturation: oxygen isotope ratios of magmatic zircon Contributions to Mineralogy and Petrology, 150 (2005), pp. 561-580

M. Wiedenbeck, P. Alle, F. Corfu, W.L. Griffin, M. Meier, F. Oberli, A. Vonquadt, J.C. Roddick, W. Speigel

Three natural zircon standards for $\mathrm{U}-\mathrm{Th}-\mathrm{Pb}, \mathrm{Lu}-\mathrm{Hf}$, trace-element and REE analyses

Geostandard Newsletter, 19 (1995), pp. 1-23

M. Wiedenbeck, J.M. Hanchar, W.H. Peck, P. Sylvester, J. Valley, M. Whitehouse, A Kronz, Y. Morishita, L. Nasdala, J. Fiebig, I. Franchi, J.P. Girard, R.C. Greenwood, R. Hinton, N. Kita, P.R.D. Mason, M. Norman, M. Ogasawara, R. Piccoli, D. Rhede, H. Satoh, B. Schulz-Dobrick, O. Skar, M.J. Spicuzza, K. Terada, A. Tindle, S. Togashi, T. Vennemann, Q. Xie, Y.F. Zheng

Further characterisation of the 91500 zircon crystal

Geostandards and Geoanalytical Research, 28 (2004), pp. 9-39

J.D. Woodhead, J.M. Hergt

Preliminary appraisal of seven natural zircon reference materials for in situ $\mathrm{Hf}$ isotope determination

Geostandards and Geoanalytical Research, 29 (2005), pp. 183-195

F.Y. Wu, Y.H. Yang, L.W. Xie, J.H. Yang, P. Xu

$\mathrm{Hf}$ isotopic compositions of the standard zircons and baddeleyites used in $\mathrm{U}-\mathrm{Pb}$ geochronology

Chemical Geology, 234 (2006), pp. 105-126 